National Marine

Fisheries Service

NOAA
Fishery Bulletin

a established in 1881 a
Spencer F. Baird

First U.S. Commissione of Fisheries and founder of Fishery Bulletin

\begin{abstract}
The velvet dogfish (Zameus squamulosus) is a wide-ranging species of shark that is captured as bycatch in bottom and pelagic longline fisheries in the Atlantic, Pacific, and Indian oceans from near the surface to depths as great as 2000 $\mathrm{m}$. Here we provide information on the vertical distribution, diet, and reproduction of the velvet dogfish based on examination of 21 specimens captured in Hawaiian longline fisheries. Only females (576-839 mm in total length [TL]) were captured in waters off Hawaii and this finding may indicate sexual segregation for this species. All individuals were captured in epipelagic and pelagic oceanic waters at estimated target hook depths between 24 and 400 $\mathrm{m}$. Stomach and intestinal contents consisted of squid, fish, and shrimp. Females were immature at 576-729 $\mathrm{mm}$ TL and mature at $715-839 \mathrm{~mm}$ TL. Mature females contained 6-10 uterine eggs and 4-8 embryos. On the basis of results from a pregnant female $(715 \mathrm{~mm}$ TL), the size of ovarian ova, and the width of the uteri of slightly larger individuals, female maturity was estimated to occur at $715-730 \mathrm{~mm}$ TL. No reproductive seasonality was detected; however, our sample size was small. Reproductive data from published records for size of near-term embryos and smallest free-swimming specimens with umbilical scars indicate that size at birth is $245-270 \mathrm{~mm}$ TL.
\end{abstract}

Manuscript submitted 18 July 2017. Manuscript accepted 2 March 2018. Fish. Bull. 116:207-214 (2018). Online publication date: 16 March 2018. doi: 10.7755/FB.116.2.9

The views and opinions expressed or implied in this article are those of the author (or authors) and do not necessarily reflect the position of the National Marine Fisheries Service, NOAA.

\title{
Vertical distribution, diet, and reproduction of the velvet dogfish (Zameus squamulosus) in waters off Hawaii
}

\author{
Gerald L. Crow (contact author) ${ }^{1}$ \\ Bradley M. Wetherbee ${ }^{2,3}$ \\ Robert L. Humphreys Jr. (retired) ${ }^{4}$ \\ Richard Young 5
}

Email address for contact author: gcrow@hawaii.edu

\author{
1 Waikiki Aquarium \\ University of Hawaii at Manoa \\ 2777 Kalakaua Avenue \\ Honolulu, Hawaii 96815 \\ 2 Department of Biological Sciences \\ University of Rhode Island \\ 9 East Alumni Road \\ Kingstown, Rhode Island 02881-0816 \\ 3 Guy Harvey Research Institute \\ Nova Southeastern University \\ 8000 North Ocean Road \\ Dania Beach, Florida 33004
}

\author{
${ }^{4}$ Life History Program \\ Fisheries Biology and Stock Assessment Branch \\ Fisheries Research and Monitoring Division \\ Pacific Islands Fisheries Science Center \\ National Marine Fisheries Service, NOAA \\ 1845 Wasp Boulevard, Building 176 \\ Honolulu, Hawaii 96818 \\ 5 Department of Oceanography \\ School of Ocean and Earth Science and \\ Technology \\ University of Hawaii at Manoa \\ 1000 Pope Road \\ Honolulu, Hawaii 96822
}

The velvet dogfish (Zameus squamulosus) is a dark, nondescript shark species with a wide distribution along the margins of the Atlantic, Pacific, and Indian ocean basins and at a number of insular regions, including the Canary Islands, Hawaii, Japan, New Zealand, Okinawa, and Palau (Compagno, 1984; Taniuchi and Garrick, 1986; Yano and Kugai, 1993; Wetherbee and Crow, 1996; Pajuelo et al., 2010). Although this species was placed in the genus Scymnodon before the revision by Taniuchi and Garrick (1986), the genus Zameus is genetically distinct from Scymnodon, and Zameus squamulosus is recognized as the valid name for the velvet dogfish (White et al., 2014). This species occurs as bycatch in a variety of fisheries, including those using trawls and pelagic or bottom longlines (Krefft, 1980; Yano and Tanaka, 1984; Nakaya and Shirai, 1992; Pajuelo et al., 2010; Zhu et al., 2012; Romanov et al., 2013) at depths of 27-2000 m (Compagno, 1984; Last and Stevens, 1994).

Although the velvet dogfish has a wide distribution and is regularly captured, information about its basic life history remains fragmentary and has been hindered by misidentification. Not surprisingly, this species is categorized in the International Union for the Conservation of $\mathrm{Na}$ ture (IUCN) Red List of Threatened Species as data deficient (Burgess and Chin, 2006), and the limited information on its basic biology, which is required to assess the status of a stock or to evaluate fisheries impact on the population, is unavailable.

Few records exist on the diet and reproductive biology of the velvet dogfish. Compagno (1984) suggested that these sharks feed on bottom fishes and invertebrates, and Kobayashi (1986) reported an octopus 


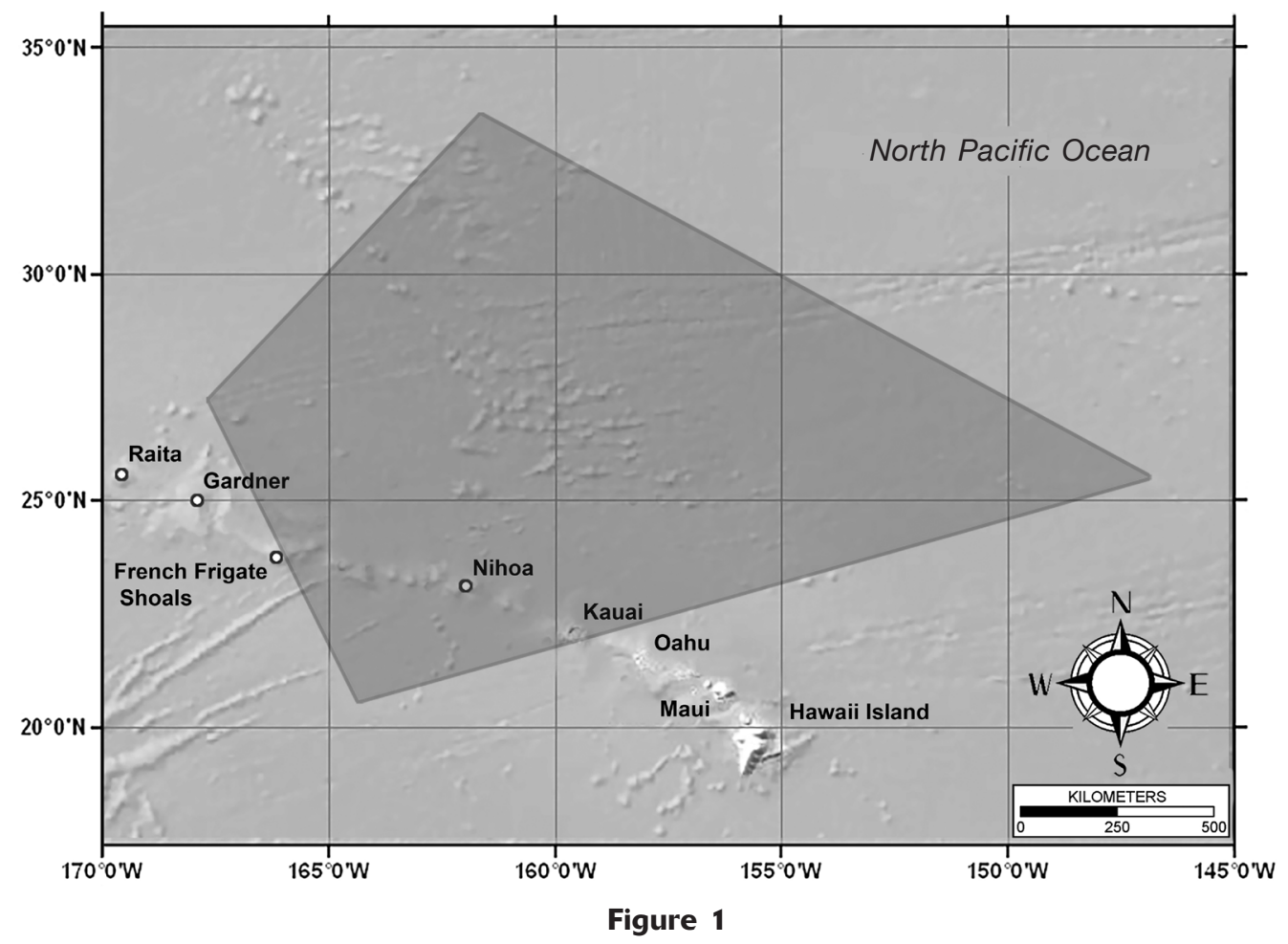

Map of the study area (darker shaded area) in the Hawaiian Archipelago, where velvet dogfish (Zameus squamulosus) were collected in Hawaii longline fisheries between 2001 and 2008 to determine their vertical distribution, diet, and reproductive stages.

in the stomach of one individual. On the basis of examination of a small number of reproductive tracts, velvet dogfish have been described as aplacental viviparous sharks that fit the type-II yolk-sac reproductive mode (in which several embryos with attached yolk sacs are contained in utero without uterine compartments) (Otake, 1990).

Male velvet dogfish are thought to mature between 493 and $522 \mathrm{~mm}$ in total length (TL) on the basis of clasper length and calcification of claspers (Krefft, 1980; Yano and Tanaka, 1984). Size at maturity for females is less certain. Melendez (1991) reported that females 510-551 mm TL were immature. Pajuelo et al. (2010) reported the smallest mature female at $571 \mathrm{~mm}$ TL, and Compagno et al. (2005) found mature females at sizes of 590-690 mm TL. However, Yano and Tanaka (1984) found that a 720-mm-TL female was immature and reported sizes between 750 and $840 \mathrm{~mm}$ TL for mature females. Brood size for velvet dogfish is not known, but Yano and Tanaka (1984) reported 3-10 ova in uteri of females, which may indicate that brood size falls within a similar range. Estimates of size at birth have spanned a large range, most likely attributable to misidentification. Ebert (2015) stated size at birth as $200 \mathrm{~mm}$ TL, and Cadenat and Blache (1981) reported free-swimming individuals as small as $246 \mathrm{~mm}$ TL. In contrast, Burgess and Chin (2006) reported sizes at birth of $68-90 \mathrm{~mm}$ TL. Individual velvet dogfish as large as $1094 \mathrm{~mm}$ TL have been noted (Pajuelo et al.,
2010); the maximum size was previously reported as $840 \mathrm{~mm}$ TL (Yano and Tanaka, 1984).

Specimens of the velvet dogfish are occasionally captured in Hawaii longline fisheries that primarily target tuna species and swordfish (Xiphias gladius) (Walsh et al., 2009). Longlines that primarily target big eye tuna (Thunnus obesus) are typically set in the morning and hauled in the evening, and longlines that target swordfish are set in the evening and retrieved during the morning (Pooley, 1993; Pradhan and Leung, 2004). This fishery generally extends into the mid-North $\mathrm{Pa}-$ cific Ocean from the Equator to $40^{\circ} \mathrm{N}$ and between longitudes $145^{\circ} \mathrm{W}$ and $175^{\circ} \mathrm{E}$ (Pradhan et al., 2003) (Fig. 1). The capture of velvet dogfish as bycatch in the Hawaii pelagic longline fishery provided an opportunity to expand our knowledge about this species. We present information on the depth distribution, diet, and female reproductive biology of velvet dogfish captured in $\mathrm{Ha}$ waii pelagic longline fisheries.

\section{Materials and methods}

\section{Vertical distribution}

We examined 21 velvet dogfish from waters off Hawaii. Identification was based on the key provided in Compagno (1984) and on proportional and morphometric measurements of specimens in Wetherbee and Crow 
(1996). Between 2001 and 2008, 19 specimens were collected through the Hawaii Longline Observer Program of the National Marine Fisheries Service, and these sharks were frozen on board the fishing vessels and retained for later examination. Two additional specimens captured by longline vessels were given directly to the authors by the fishermen of these longline vessels and were frozen until examined.

Estimated hook depth was based on target set depth designated by the boat captain for the deepest part of the longline and based on an approximation of individual hook positions on the longline. The median depth of the deepest hook on 266 deep sets (tuna sets) was $248 \mathrm{~m}$, whereas data for 333 shallow sets (swordfish sets) indicated a median depth of $60 \mathrm{~m}$ (Bigelow et. al., 2006). Previous reports on data from temperature-anddepth recorders attached to longlines of fishing vessels in Hawaii indicated that about $70 \%$ of deep sets were close to targeted set depth (Bigelow et al., 2006). Therefore, records of hook depth of individual longline sets provide an estimated target depth for the capture of velvet dogfish.

Frozen specimens were thawed and measured for TL, which was measured with calipers to the nearest $0.1 \mathrm{~mm}$; placing the shark on its side and its tail in the "natural" position, we measured in a straight line from the tip of the snout along the body axis to a point where a straight edge indicated a $90^{\circ}$ angle to the body axis from the posterior caudal tip. The shark was then dissected, stomach and valvular intestine were examined for food contents, and its entire reproductive anatomy was examined.

\section{Diet}

The primary bait used with tuna longlines was Pacific saury (Cololabis saira), which can be recognized in the gut and excluded from a dietary analysis. Stomachs and valvular intestines were dissected carefully, and the contents were retained within a hand net made of a $800-\mu$ fine mesh. Squid beaks, fish remains, and shrimp present in stomachs were preserved in $4-10 \%$ formalin for 3-10 d and then transferred to jars that contained 40-50\% isopropanol for storage until analyzed under a dissection microscope and identified to the lowest recognizable taxa taxon. Squid beaks were identified by identified by a coauthor (RY).

\section{Female reproductive biology}

Reproductive tracts were examined to determine the stage of sexual maturity and reproductive status of specimens. Presence of ovarian ova, diameter and location of eggs, uterus width, and number of embryos were used to assess female reproductive biology. Ovarian ova, uterine ova, and uterine embryos were counted, and maximum ova diameter and uterine width were measured with calipers to the nearest $0.1 \mathrm{~mm}$. The reproductive biology terms that we use were modified from that used by Tanaka et al. (1990) for the frill shark (Chlamydoselachus anguineus) and by Yano (1995) for the black dogfish (Centroscyllium fabricii). Sexual maturity was determined on the basis of the size of ovarian ova and uterine width. Females with ovarian ova diameters $<10 \mathrm{~mm}$ and with thread-like uteri $(<10 \mathrm{~mm}$ in width) were classified as immature. Females with both ovarian ova and uteri $>10 \mathrm{~mm}$ were classified as mature. The reproductive classification that we used for mature females had 7 stages: 1) developing ova, nongravid, with developing ovarian ova and expanded uteri (>10 mm); 2) large ova nongravid, with ova and expanded uteri (>10 mm); 3) ovulating, with eggs in body cavity; 4) uterine ova, ova in the uteri after ovulation; 5) developing embryos, obvious embryos with yolk sacs in the uteri; 6) near-term embryos, uterine embryos that have absorbed their external yolk sac; and 7) postpartum stage: no uterine embryos and large flaccid uteri (>20 mm). Although no near-term embryos were observed in utero in velvet dogfish collected off Hawaii, size at birth was estimated from lengths of near-term embryos (Graham ${ }^{1}$; Romanov ${ }^{2}$ ) and size of the smallest free-swimming individuals (Graham ${ }^{1}$; Cadenat and Blache, 1981; Yano and Tanaka, 1984; Taniuchi and Garrick, 1986).

\section{Results}

\section{Vertical distribution}

All 21 velvet dogfish obtained from Hawaii longline fisheries were females. Estimated target depths of longline sets were between 24 and $400 \mathrm{~m}$ (median depth: $182 \mathrm{~m}$ [Table 1]). Females ranged in size from 576 to $839 \mathrm{~mm}$ TL. Specimens were captured within an area between $21-34^{\circ} \mathrm{N}$ and $148-168^{\circ} \mathrm{W}$, and the majority of specimens were captured north of the Hawaiian Archipelago. The majority of sharks were captured on tuna longlines set in the morning between 0550 and 1144 , timing that is characteristic of the deep-set tuna fishing method. An exception was a shark caught on a longline deployed at 1506. The deep-set tuna longline sets had a soak time of 6-11 h and typically were retrieved between 1505 and 2331 on the same day that they were deployed.

\section{Diet}

Nine of the 21 sharks examined had recognizable stomach or intestinal contents of mesopelagic and epipelagic prey (Table 2). Seven sharks contained squid beaks, squid eye lenses, and squid gladii. Fish remains (skin, eye lenses) were present in 4 sharks, and a shrimp

\footnotetext{
${ }^{1}$ Graham, A. 2016. Personal commun. Australian National Fish Collection, CSIRO, G.P.O. Box 1538, Hobart, Tasmania 7001, Australia.

2 Romanov, E. 2016. Personal commun. Centre Technique d'Appui à la Péche ReUNionaise (CAP RUN), Darse de Pêche, Magasin 10, Port Ouest, 97420 Le Port, Île de Réunion, France.
} 
Table 1

Capture records and reproductive biology for female velvet dogfish (Zameus squamulosus) collected from Hawaii longline fisheries between 1995 and 2008. The letters $a$ and $b$ indicate different velvet dogfish caught on the same longline set. $\mathrm{N} / \mathrm{A}=$ not available.

\begin{tabular}{|c|c|c|c|c|c|}
\hline ID no. & $\begin{array}{l}\text { Capture } \\
\text { date }\end{array}$ & $\begin{array}{c}\text { Total } \\
\text { length } \\
(\mathrm{mm})\end{array}$ & $\begin{array}{l}\text { Estimated } \\
\text { hook depth } \\
\text { (m) }\end{array}$ & $\begin{array}{c}\text { Maturity } \\
\text { status }\end{array}$ & Reproductive status \\
\hline 1 & 15 Oct 95 & 786 & 30 & Mature & 8 ovarian eggs; largest $37 \mathrm{~mm}$; uterus width $18.5 \mathrm{~mm}$ \\
\hline 2 & N/A & 746 & N/A & Mature & 7 ovarian eggs; largest $52.8 \mathrm{~mm}$ \\
\hline 3 & 24 Sep 01 & 720 & N/A & Mature & Uterine eggs; largest $47.9 \mathrm{~mm}$ \\
\hline 4 & 07 Oct 01 & 735 & 24 & Mature & 6 ovarian eggs; range $35.5-47.5 \mathrm{~mm}$ \\
\hline 5 & 12 Nov 01 & 758 & 400 & Mature & 9 ovarian eggs; range $44.4-56.5 \mathrm{~mm}$ \\
\hline 6 & 10 Nov 01 & 594 & 305 & Immature & No sexual development \\
\hline 7 & 16 Dec 01 & 728 & 250 & Immature & No sexual development \\
\hline 8 & 10 Feb 02 & 576 & 364 & Immature & No sexual development \\
\hline 9 & N/A & 728 & N/A & Mature & Uterine eggs not measured \\
\hline 10 & $28 \mathrm{Jul} 02$ & 752 & 110 & Mature & Small ovarian eggs: largest $8.2 \mathrm{~mm}$; uterus width $29-33 \mathrm{~mm}$ \\
\hline 11 & 26 Aug 02 & 791 & 180 & Mature & 4 embryos; range $31.4-36.7 \mathrm{~mm}$ TL \\
\hline 12 & 10 Sep 02 & 729 & 300 & Immature & 9 ovarian eggs: largest $34.4 \mathrm{~mm}$; uterus width $8.6 \mathrm{~mm}$ \\
\hline 13 & 24 Mar 03 & 736 & 120 & Mature & 9 ovarian eggs; range $18.9-22.3 \mathrm{~mm}$ \\
\hline 14 & 23 Nov 08 & 805 & N/A & Mature & 8 uterine eggs (not measured) \\
\hline 15 & 08 May 08 & 715 & 83 & Mature & 8 embryos; range $44.5-60.4 \mathrm{~mm}$ TL \\
\hline 16 & 27 Apr 08 & 720 & 71 & Mature & Ovary starting to develop; uterus width $10.5 \mathrm{~mm}$ \\
\hline 17 & 18 Aug 06 & 751 & 182 & Mature & Ovary and uteri developed \\
\hline 18 & 28 Apr 08 & 722 & 82 & Mature & Eggs ruptured in abdominal cavity \\
\hline 19 & 12 Nov 01 & 720 & 400 & Mature & 10 ovarian eggs; range $25.3-28.8 \mathrm{~mm}$; uterus width $15.5 \mathrm{~mm}$ \\
\hline $20^{\mathrm{a}}$ & $07 \mathrm{Jul} 06$ & 742 & 182 & Mature & 10 uterine eggs (not measured); uterus width $41.1 \mathrm{~mm}$ \\
\hline $21^{\mathrm{b}}$ & 07 Jul 06 & 839 & 182 & Mature & 9 uterine eggs; range $38.5-47.7 \mathrm{~mm}$ \\
\hline
\end{tabular}

was present in 1 shark. Identifiable squid beaks represented 4 families; 2 identified species, Nototodarus hawaiiensis and Sandalops melancholicus; and 3 recognizable genera, Histioteuthis, Onykia, and Walvisteuthis (Table 2).

\section{Female reproductive biology}

Seventeen of the 21 examined velvet dogfish were mature. Both left and right ovaries of female velvet dogfish were functional. Uteri were noncompartmentalized and contained 6-10 ova that were between 36.7 and $52.8 \mathrm{~mm}$ in diameter. It is unclear whether all uterine eggs were fertilized. Four females between 576 and $729 \mathrm{~mm}$ TL had small, developing ovaries $(<10 \mathrm{~mm}$ in diameter) and narrow uteri $(<10 \mathrm{~mm}$ in width) and were classified as immature (Table 1). Seventeen females, ranging in size between 715 and $839 \mathrm{~mm}$ TL, had ova $>10 \mathrm{~mm}$ in diameter and expanded uteri $(>10$ $\mathrm{mm}$ in width) and were classified as mature (Table 1). Six of the 7 stages of reproductive maturity for females were observed in the specimens from Hawaii. No nearterm embryos were found. Large ova (>30 mm) were observed in ovaries of velvet dogfish captured during September, October, and November. The smallest pregnant female was $715 \mathrm{~mm}$ TL. Uterine eggs were observed in specimens collected during July, September, and November, and developing embryos were found in uteri of sharks obtained in May and August (Table 3). No reproductive seasonality could be detected from our limited sample size (Tables 1 and 3 ).

Brood sizes of 2 pregnant females were 4 and 8 embryos, and these ranged from 31.4 to $36.7 \mathrm{~mm}$ TL in August and between 45.5 and $60.4 \mathrm{~mm}$ TL in May. On the basis of the presence of yolk sacs and size of the embryos, we determined that none of them were considered near-term embryos.

\section{Discussion}

\section{Vertical distribution}

The capture of velvet dogfish in Hawaii pelagic longline fisheries, is not as rare an event as previously suggested (Wetherbee and Crow, 1996). The worldwide distribution of this species includes a number of insular locations, such as Hawaii, and other waters in the Pacific Ocean, the Atlantic Ocean, and the Indian Ocean, and indicates that this species is associated with islands in addition to continental slope habitats.

The estimated hooking depths for shark captures off Hawaii (24-400 m) and similar pelagic depths reported in other studies (Yano and Tanaka, 1984; Dai et al., 


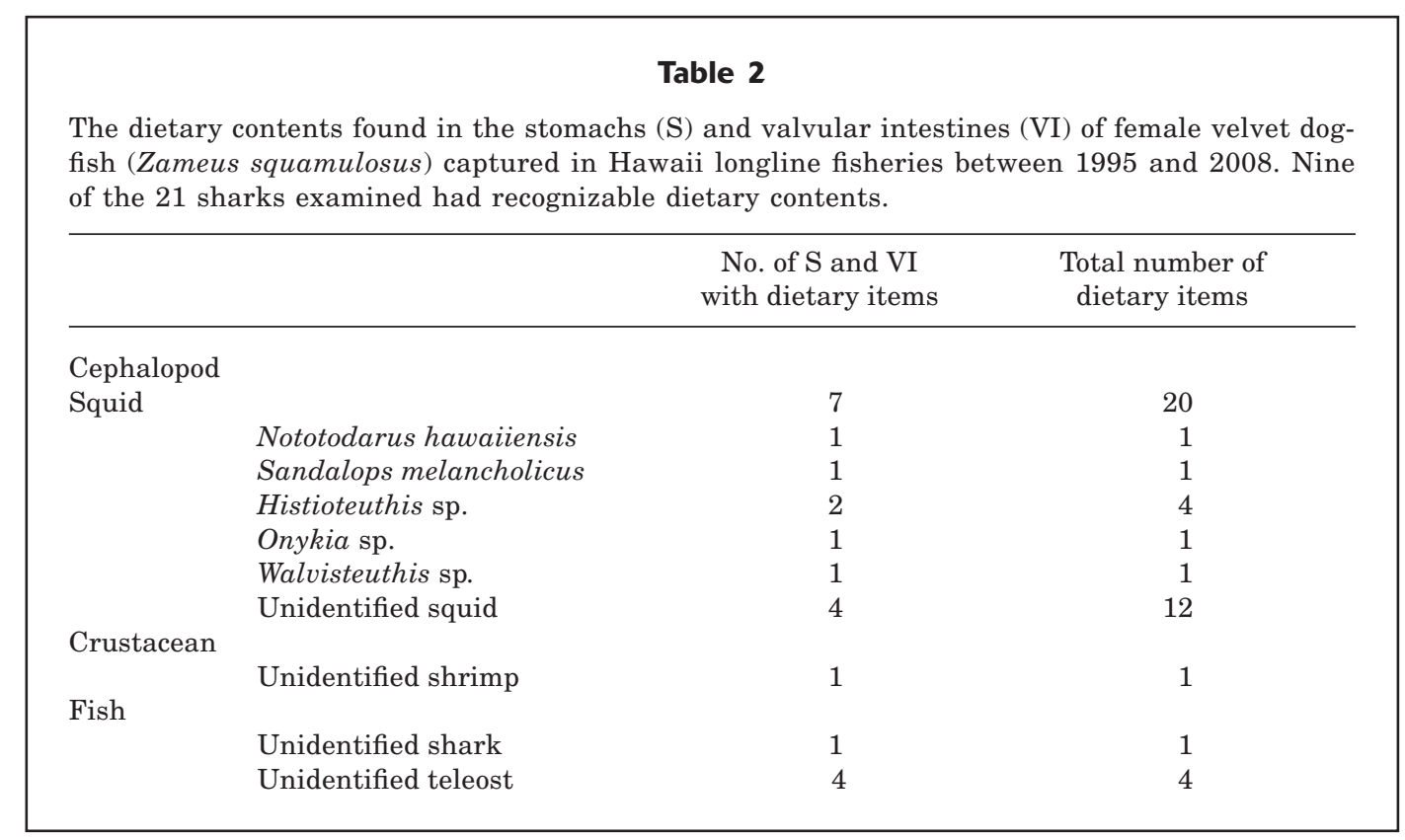

Table 3

Number of female velvet dogfish (Zameus squamulosus), collected and retained each month from Hawaii longline fisheries between 1995 and 2008, classified as immature (IM) or in 1 of 7 stages of reproductive maturity: nongravid females with developing ovarian eggs (DO), nongravid females holding at least one large ovarian egg (LO), ovulating females (OV), postovulatory females with uterine ova (UO), gravid females carrying at least one encapsulated developing embryo (DE), gravid females carrying near-term embryos free in the uterus (NE), and postpartum females (PP). Table format is adapted from Tanaka et al. (1990) and Yano (1995).

\begin{tabular}{|c|c|c|c|c|c|c|c|c|c|}
\hline Month & IM & DO & LO & OV & UO & $\mathrm{DE}$ & $\mathrm{NE}$ & $\mathrm{PP}$ & Total \\
\hline Jan & & & & & & & & & 0 \\
\hline Feb & 1 & & & & & & & & 1 \\
\hline Mar & & 1 & & & & & & & 1 \\
\hline Apr & & 1 & & 1 & & & & & 2 \\
\hline May & & & & & & 1 & & & 1 \\
\hline Jun & & & & & & & & & 0 \\
\hline Jul & & & & & 2 & & & 1 & 3 \\
\hline Aug & & & & & & 1 & & 1 & 2 \\
\hline Sep & 1 & & & & 1 & & & & 2 \\
\hline Oct & & & 2 & & & & & & 2 \\
\hline Nov & 1 & & 1 & & 2 & & & & 4 \\
\hline Dec & 1 & & & & & & & & 1 \\
\hline
\end{tabular}

2006; Zhu et al., 2012; Romanov et al., 2013) indicate that female velvet dogfish clearly exhibit an epipelagic aspect in their behavior. The capture of this species at depths as great as $2000 \mathrm{~m}$ also reveals a large vertical and benthic range in their movements (Pajuelo et al., 2010; Romanov et al., 2013). In general, larger squaloid sharks similar in size to velvet dogfish tend to be benthic, slope, or shelf dwellers, whereas the majority of oceanic dogfish species are smaller species (Hubbs et al., 1967; Pikitch et al., 2008). Female velvet dogfish regularly inhabit pelagic waters, and this relatively large squaloid may transition from bottom to midwater or pelagic waters to take advantage of feeding opportunities, probably by following migrations of midwater squid and fish (Parin, 1970; Krefft, 1980).

The capture of only females off Hawaii raises the possibility of sexual segregation, because females more frequently use the epipelagic environment and males remain more bottom oriented at greater depths. Sexual segregation for this species at other locations is indicated by the capture of only females on floating longlines in the northwestern North Pacific Ocean (Yano 
and Tanaka, 1984) and a female:male ratio of 4.1:1.0 of velvet dogfish captured at the Canary Islands (Pajuelo et al., 2010). Segregation may result from the movement of females from depth to epipelagic water because a 1:1 sex ratio has been reported for velvet dogfish captured on bottom longlines at depths as great as $1000 \mathrm{~m}$ (Kobayashi, 1986; Nakaya and Shirai, 1992; Yano and Kugai, 1993). Sexual segregation has been reported for other members of the family Somniosidae, including the roughskin dogfish (Centroscymnus owstonii) and the Portuguese shark (C. coelolepis) (Yano and Tanaka, 1988; Girard and Du Buit, 1999), both of which are relatively large squaloid sharks.

Females captured in our study were mature or approaching maturity and therefore indicated that velvet dogfish may also segregate by size. Segregation may reflect the movement of mature females into epipelagic waters, and such movement may be related to reproduction rather than to feeding. There is evidence of segregation by size for a number of species of dogfish, including the closely related Japanese velvet dogfish (Scymnodon ichiharai): large individuals are thought to be more common inside the boundary of Suruga Bay, Japan, than smaller, immature individuals (Yano and Tanaka, 1984).

\section{Diet}

Our findings indicate that velvet dogfish feed primarily on squid and less on fish and shrimp; however, these results may be biased as a result of the longer retention of squid beaks in stomachs because of their resistance to digestion than the retention of other invertebrate prey or fish (Hyslop, 1980). The stomachs and intestines of females captured in the upper water column were examined for remains of prey and from an examination of these organs, squid appear to form the major portion of the diet. It is not surprising that squid are a major food item of the velvet dogfish in waters surrounding Hawaii, given the abundance of a number of species of squid that occur in this region. The greatest trawl catches for a wide range of cephalopod species in Hawaii have been recorded at night in the upper $200 \mathrm{~m}$ (Young, 1978). Many of these cephalopod species are thought to undergo a diel vertical migration from daytime depths of 400-700 $\mathrm{m}$ to shallower nighttime depths of 250-300 m (Young, 1978). The well-developed tail of velvet dogfish and the depth distribution of the various squid consumed by the dogfish examined indicate that the velvet dogfish may be an active feeder or an ambush predator in the epipelagic and mesopelagic zones. Active predation on pelagic cephalopods by adult and subadult Portuguese sharks in the Catalan Sea was also reported by Carrassón et al. (1992).

\section{Female reproductive biology}

Although the number of velvet dogfish specimens examined in our study was small, the information gained from our examination of these sharks expands our un- derstanding of the reproductive biology of females of this species. Yano and Tanaka (1984) reported 3-10 ova in uteri of female velvet dogfish; however, actual brood size may be less in other squaloid sharks (i.e., 20-31 uterine ova and 16-28 embryos for the roughskin dogfish and 22-29 uterine ova and 15-29 embryos for the Portuguese shark) in Suruga Bay, Japan (Yano and Tanaka, 1988). The brood size for velvet dogfish examined in this study was $2-8$ young. Five embryos 200-220 $\mathrm{mm}$ TL have been observed in the last third of the gestation period (Romanov et al., 2013; Gra$h^{1}{ }^{1}$. Size at birth for velvet dogfish is estimated at 245-270 mm TL on the basis of observations of embryos with yolk sac attached at sizes of $200-220 \mathrm{~mm}$ TL (A. Graham ${ }^{1}$ ), free-swimming sharks $250-270 \mathrm{~mm}$ TL with faint umbilical scars (Graham ${ }^{1}$; Romanov ${ }^{2}$ ), and a 277-mm-TL free-swimming shark with an umbilical scar completely healed $\left(\right.$ Graham $\left.^{1}\right)$. The minimum sizes reported for free-swimming individuals were 246-262 mm TL (Cadenat and Blache, 1981; Yano and Tanaka, 1984; Taniuchi and Garrick, 1986; (Graham ${ }^{1}$ ). This information substantially narrows the range for estimates of size at birth from the large size $(690 \mathrm{~mm}$ TL) previously reported by Burgess and Chin (2006) and the small size (200 mm TL) reported in Ebert (2015).

The estimated size at maturity for females was between 715 and $730 \mathrm{~mm}$ TL in our study and was based on the size of a 715-mm-TL pregnant female and immature individuals approaching $730 \mathrm{~mm}$ TL. These estimates reduce the size range at sexual maturity. Our estimate of size at maturity for females is substantially larger than the estimate of $590 \mathrm{~mm}$ TL reported by Compagno et al. (2005). Our current hypothesis is that there is no annual seasonal cycle of reproduction for this species; however, more data are required to confirm this notion. In waters off Hawaii, ovulating females and early-stage gravid females (small embryos 31.1-60.4 mm) were observed between April and August. Lack of a seasonal reproductive cycle is a common feature of squaloid sharks (Yano and Tanaka, 1984). The entirety of data available on reproduction in female velvet dogfish provides some evidence that they may be associated with the benthic habitat for parturition because of the capture of small, free-swimming individuals and females with near-term embryos in utero on bottom longlines (Romanov et al., 2013).

The velvet dogfish is an enigmatic species captured across a wide geographical range and throughout a range of depths in the water column. However, this species is rare in pelagic fisheries, and therefore it is typically caught in low numbers in fisheries around the world. For example, Dai et al. (2006) reported a catch per unit of effort (CPUE) for velvet dogfish of only 0.007 individuals $/ 1000$ hooks for longline fisheries in the eastern Pacific Ocean. In the Hawaii longline fisheries (swordfish and tuna longlines combined) during 1995-2006, the CPUE of velvet dogfish was $0.005 / 1000$ hooks (Walsh et al., 2009). In the eastern central Pacific Ocean, velvet dogfish were caught primarily at a median depth of $190 \mathrm{~m}$, and the box plot of 25 and 
75 percentiles was in a range of $165-210 \mathrm{~m}$ (Zhu et al., 2012). This range is similar to the median depth of $248 \mathrm{~m}$ reported for the tuna longline fishery in the Hawaiian Islands (Bigelow et al., 2006). The CPUE for velvet dogfish in Hawaii likely would be slightly higher if only tuna longlines were considered.

There is some evidence that bycatch of velvet dogfish in commercial fisheries is increasing. Romanov et al. (2013) reported increased numbers of velvet dogfish caught in pelagic fisheries in the Indian Ocean since 1989 , but this species was not reported as bycatch in this fishery from 1961 to 1989 . They suggested that increased abundance of velvet dogfish and other mid-size oceanic predators in pelagic fisheries may be related to broad ecological shifts in oceanic waters that have occurred over the past few decades. Polovina et al. (2009) suggested that recent increases in abundance of other mid-size mesopredators, including bramids (pomfrets) and gempylids (snake mackerels) in pelagic fisheries operating from Hawaii may be attributed to a reduction in apex predators in this ecosystem. The increasing presence of velvet dogfish in the bycatch of pelagic fisheries may be a harbinger of a shift that will occur in these fisheries. The ecological position and population dynamics of mesopredators and their link to fisheries are important considerations for the management of these species.

\section{Acknowledgments}

We thank the Observer Program of the NOAA Pacific Islands Regional Office and longline captains for collecting the specimens under Institutional Animal Care and Use Committee Southwest Pacific Islands protocols (IACUC SWPI 2015-2 and 14-1751-3) and providing capture information. The NOAA Pacific Islands Fisheries Science Center (PIFSC) provided freezer and laboratory space. M. Sundberg-Luers and A. Andrews (PIFSC) provided additional longline catch data and Figure 1. We thank A. Graham and E. Romanov for supplying personal records and collection data.

\section{Literature cited}

Bigelow, K., M. K. Musyl, F. Poisson, and P. Kleiber. 2006. Pelagic longline gear depth and shoaling. Fish. Res. 77:173-183. Article

Burgess, G. H., and A. Chin.

2006. Zameus squamulosus. The IUCN Red List of Threatened Species 2006: e.T60215A12322535. [Available from website, accessed January 2016.]

Cadenat, J., and J. Blache.

1981. Requins de Méditerranée et d'Atlantique (plus particulièrement de la Côte Occidentale d' Afrique). Faune Trop. 21:1-330.

Carrassón, M., C. Stefanescu, and J. E. Cartes.

1992. Diets and bathymetric distributions of two bathyal sharks of the Catalan deep Sea (western Mediterranean). Mar. Ecol. Prog. Ser. 82:21-30.
Compagno, L. J. V.

1984. FAO species catalogue. Vol 4. Sharks of the world. An annotated and illustrated catalogue of shark species known to date. Part 1-Hexanchiformes to Lamniformes. FAO Fish. Synop. 125, 249 p. FAO, Rome.

Compagno, L., M. Dando, and S. Fowler.

2005. Sharks of the world, 496 p. Princeton Univ. Press, Princeton, NJ.

Dai, X.-J., L.-X. Xu, L.-M. Song, Y.-C. Liu.

2006. Analysis on shark species and catch by tuna longline fishery in the eastern Pacific Ocean. J. Shanghai Fish. Univ. 15:509-513.

Ebert, D. A

2015. Deep-sea cartilaginous fishes of the southeastern Atlantic Ocean. FAO Species Catalogue for Fishery Purposes 9, 251 p. FAO, Rome.

Girard, M., and M.-H. Du Buit.

1999. Reproductive biology of two deep-water sharks from the British Isles, Centroscymnus coelolepis and Centrophorus squamosus (Chondrichthyes: Squalidae). J. Mar. Biol. Assoc. U.K. 79:923-931.

Hubbs, C. L., T. Iwai, and K. Matsubara.

1967. External and internal characters, horizontal and vertical distributions, luminescence, and food of the dwarf pelagic shark, Euprotomicrus bispinatus. Bull. Scripps Inst. Oceanogr. 10:1-81.

Hyslop, E. J.

1980. Stomach contents analysis-a review of methods and their application. J. Fish Biol. 17:411-429. Article

Kobayashi, H.

1986. Studies on deep-sea sharks in Kumano-nada region. Bull. Fac. Fish. Mie Univ. No. 13:25-133.

Krefft, G.

1980. Results of the research cruises of FRV "Walter Herwig" to South America. LIII*). Sharks from the pelagic trawl catches obtained during Atlantic transects, including some specimens from other cruises. Arch. Fischereiwiss. 30:1-16.

Last, P. R., and J. D. Stevens.

1994. Sharks and rays of Australia, 513 p. CSIRO, Melbourne, Australia.

Melendez, R. C.

1991. Zameus squamulosus (Günther, 1877) en Chile (Chondrichthyes, Squaliformes, Squalidae). Invest. Pesq. (Chile) 36:89-95.

Nakaya, K., and S. Shirai.

1992. Fauna and zoogeography of deep-benthic chondrichthyan fishes around the Japanese Archipelago. Jpn. J. Ichthyol. 39:37-48.

Otake, T.

1990. Classification of reproductive modes in sharks with comments on female reproductive tissues and structures. In Elasmobranchs as living resources: advances in the biology, ecology, systematics, and the status of the fisheries (H. L. Pratt Jr., S. H. Gruber, and T. Taniuchi, eds.), p. 111-130. NOAA Tech. Rep. NMFS 90.

Pajuelo J. G., J. A. González, and J. I. Santana.

2010. Bycatch and incidental catch of the black scabbardfish (Aphanopus spp.) fishery off the Canary Islands. Fish. Res. 106:448-453. Article

Parin, N. V.

1970. Ichthyofauna of the epipelagic zone, $186 \mathrm{p}$. Israel Program for Scientific Translation, Jerusalem, Israel. 
Pikitch, E. K., M. D. Camhi, and E. A. Babcock.

2008. Introduction to sharks of the open ocean. In Sharks of the open ocean: biology, fisheries and conservation (M. D. Camhi, E. K. Pikitch, and E. A. Babcock, eds.), p. 1-13. Blackwell Publishers, Ltd., Oxford, UK.

Polovina, J. J., M. Abecassis, E. A. Howell, and P. Woodworth. 2009. Increases in the relative abundance of mid-trophic level fishes concurrent with declines in apex predators in the subtropical North Pacific. Fish. Bull. 107:523-531.

Pooley, S. G.

1993. Hawaii's marine fisheries: some history, long-term trends, and recent developments. Mar. Fish. Rev. $55: 7-19$.

Pradhan, N. C., and P. Leung.

2004. Modeling trip choice behavior of the longline fishers in Hawaii. Fish. Res. 68:209-224. Article

Pradhan, N. C., K. R. Sharma, and P. Leung

2003. Analyzing technical and economic interrelationships in Hawaii's longline fishery. Mar. Resour. Econ. 18:167-193. Article

Romanov, E. V., P. Bach, S. T. Rebik, A. Le Turc, and B. Séret. 2013. First pelagic record of the velvet dogfish Zameus squamulosus (Günther, 1877) (Squaliformes) from the southwestern Indian Ocean and some notes on its regional distribution. Zoosystema 35:11-23.

Tanaka, S., Y. Shiobara, S. Hioki, H. Abe, G. Nishi, K. Yano, and K. Suzuki.

1990. The reproductive biology of the frilled shark, Chlamydoselachus anguineus, from Suruga Bay, Japan. Jpn. J. Ichthyol. 37:273-291.

Taniuchi, T., and J. A. F. Garrick.

1986. A new species of Scymnodalatias from the southern oceans, and comments on other squaliform sharks. Jpn. J. Ichthyol. 33:119-134.

Walsh, W. A., K. A. Bigelow, and K. L. Sender. 2009. Decreases in shark catches and mortality in the Hawaii-based longline fishery as documented by fishery observers. Mar. Coast. Fish. 1:270-282. Article
Wetherbee, B. M., and G. L. Crow.

1996. First record of the squaloid shark Scymnodon squamulosus from the Hawaiian Islands. Ichthyol. Res. 43:334339. Article

White, W. T., D. F. B. Vaz, H.-C. Ho, D. A. Ebert, M. R. de Carvalho, S. Corrigan, E. Rochel, M. de Carvalho, S. Tanaka, and G. J. P. Naylor.

2014. Redescription of Scymnodon ichiharai Yano and Tanaka 1984 (Squaliformes: Somniosidae) from the western North Pacific, with comments on the definition of somniosid genera. Ichthyol. Res. 62:213-229. Article

Yano, K.

1995. Reproductive biology of the black dogfish, Centroscyllium fabricii, collected from waters off western Greenland. J. Mar. Biol. Assoc. U.K. 75:285-310. Article

Yano, K., and S. Tanaka.

1984. Review of the deep sea sqauloid shark genus Scymnodon of Japan, with a description of a new species. Jpn. J. Ichthyol. 30:341-360. Article

1988. Size at maturity, reproductive cycle, fecundity, and depth segregation of the deep sea squaloid sharks Centroscymnus owstoni and C. coelolepis in Suruga Bay, Japan. Nippon Suisan Gakkaishi 54:167-174. Article

Yano, K., and K. Kugai.

1993. Deep-sea chondrichthyans collected from the waters around the Okinawa Islands: results of catch analysis of bottom longlines. Bull. Seikai Natl. Fish Res. Inst. 71:51-65.

Young, R. E.

1978. Vertical distribution and photosensitive vesicles of pelagic cephalopods from Hawaiian waters. Fish. Bull. 76:583-615.

Zhu, J., L. Xu, X. Dai, X. Chen, and Y. Chen.

2012. Comparative analysis of depth distribution for seventeen large pelagic fish species captured in a longline fishery in the central-eastern Pacific Ocean. Sci. Mar. 76:149-157. Article 